\title{
Analisis Pergeseran \\ Struktur Ekonomi Kabupaten Berau \\ Sebelum dan Setelah Otonomi Daerah
}

\author{
Shorea Helminasari \\ Dosen Ilmu Administrasi Negara FISIP Universitas Widya Gama Mahakam Samarinda \\ E-mail: rheahamasaki@gmail.com
}

\begin{abstract}
ABSTRAK
Pembangunan ekonomi yang diringi dengan pertumbuhan ekonomi yang berkesinambungan dapat menyebabkan terjadinya perubahan pola struktur ekonomi di suatu wailayah. Perubahan pola ini terjadi karena kontribusi dari masing-masing sektor ekonomi mengalami pergesaran. Penelitian ini dilkakukan untuk menganalisis perubahan pola struktur ekonomi Kabupaten Berau sebelum dan setelah otonomi daerah dengan Provinsi Kalimantan Timur sebagai wilayah acuan serta menganalisis pergeseran yang terjadi antara pertumbuhan ekonomi secara keseluruhan dan pertumbuhan ekonomi sektoral di tingkat wilayah acuan serta pertumbuhan ekonomi di tingkat lokal.

Data yang digunakan dalam penelitian ini adalah PDRB Kabupaten Berau atas dasar harga konstan (ADHK) dan PDRB Kalimantan Timur atas dasar harga konstan (ADHK) sebelum otonomi daerah dari tahun 1993-2000 dan setelah otonomi daerah dari tahun 2000-2011.

Metode penelitian yang digunakan adalah analisis shift share. Penulis menggunakan perhitungan sebelum dan setelah otonomi daerah dengan mengelompokkan tiga kelompok sektor yaitu sektor primer, sekunder dan tersier membandingkan dari tahun ketahun yang mana lebih dominan.

Berdasarkan hasil kajian disimpulkan bahwa pola struktur ekonomi dalam penelitian ini yaitu sebelum otonomi daerah tahun 1993-2000 dan setelah otonomi daerah tahun 2000-2011 dapat dibagi menjadi 2 (dua) pola yaitu pola struktur ekonomi yang cendrung konstan dan pola struktur ekonomi yang berfluktuatif. Sektor ekonomi yang memiliki kecendrungan berpola fluktuatif terjadi sebelum otonomi daerah tahun 1993-2000 dimana pada tahun 1993-1995 sektor primer yang mendominasi dan pada tahun 1996-1997 sektor sekunder yang mendominasi pada tahun 1997-1998 sektor primer yang mendominasi pada tahun 1998-1999 kembali sektor tersier kembali yang mendominasi dan pada tahun 1999-2000 sektor primer yang mendominasi, sedangkan sektor ekonomi yang memiliki kecendrungan berpola konstan terjadi setelah otonomi daerah yaitu dari tahun 2000-2011 dimana sektor primer dominan disusul tersier dan terakhir sektor sekunder.

Hasil penelitian ini diharapkan dapat menjadi masukan bagi para pengambil kebijakan di Kabupaten Berau untuk dapat mencari solusi yang terbaik dalm pengembangan perekonomian Kabupaten Berau di masa yang kan datang.
\end{abstract}

Kata Kunci : Pola struktur ekonomi, pergeseran struktur ekonomi dan alalisis shift share 


\section{Abstract}

Economic development is accompanied by sustained economic growth can lead to changes in the pattern of economic structure in the region. Changes in these patterns occur because of the contribution of each sector of the economy experienced a shift. This study was conducted to analyze the changes in the pattern of economic structure Berau district before and after the regional autonomy with the Province of East Kalimantan as a reference region and analyze the shift between overall economic growth and economic growth at the regional level reference sectoral and economic growth at the local level.

The data used in this study is the Berau Regency GRDP at constant prices (ADHK) and East Kalimantan GRDP at constant prices (ADHK) before decentralization from the year 1993 to 2000 and after the regional autonomy of the year 2000-2011.

The method used is the shift share analysis. The author uses calculations before and after the regional autonomy by grouping three groups namely the sectors of primary, secondary and tertiary compare from year to year which is more dominant.

Based on the results of the study concluded that the pattern of economic structure in this research that prior to decentralization in 1993-2000 and after decentralization in 2000-2011 can be divided into two (2) pattern is a pattern of economic structure tends to a constant and fluctuating pattern of economic structure. The economic sectors that have a tendency to fluctuate patterned occur prior to decentralization in 1993-2000 where in the primary sector 1993-1995 and in 1996-1997 dominates the secondary sector that dominates in 1997-1998 that dominates the primary sector in 1998-1999 back the tertiary sector that dominates the back and in 1999-2000 the primary sector predominates, while the economic sector that has a constant tendency occurs patterned after the regional autonomy that is from the year 2000-2011 in which the dominant primary sector followed by the tertiary and secondary sectors last.

The result is expected to be input for policy makers in Berau order to find the best solution preformance Berau District economic development in the coming future.

Keywords: pattern of economic structure, shifting the economic structure and shift share alalisis.

\section{Latar Belakang}

Indonesia terdiridaribeberapawilayah yang memiliki struktur perekonomian yang beraneka ragam. Struktur ekonomi dapat dilihat dari peran/kontribusi dari masing-masing sektor perekonomian. Pada tahap-tahap awal pembangunan menunjukkan bahwa sektor primer memiliki peran penting dalam pembentukan pendapatan suatu wilayah/negara. Pembangunan lebih lanjut membuat peran/kontribusi sektor primer berkurang dan peran ini berpindah ke sektor sekunder dan tersier. Turunnya peran/kontribusi sektor primer di semua wilayah tidaklah berarti sektor primer di semua wilayah nilai tambahnya turun. Pada kenyataannya nilai tambahnya selalu meningkat, akan tetapi pertumbuhan nilai tambah pada sektor lainnya juga meningkat lebih tinggi. Perubahan struktur ekonomi wilayah-wilayah di Indonesia dipengaruhi oleh potensi yang dipunyai wilayah yaitu sumber-sumber yang ada (Adi, 2001).

Pembangunan daerah sebagai tolak ukur pertumbuhan ekonomi memprioritaskan untuk 
membangun dan memperkuat sektor-sektor di bidang ekonomi dengan mengembangkan, meningkatkan dan mendayagunakan sumber daya secara optimal dengan tetap memperhatikan ketentuan antara industri dan pertanian yang tangguh serta sektor pembangunan lainnya. Sektor ekonomi terdiri atas sembilan sektor yaitu: (1) pertanian; (2) pertambangan dan penggalian; (3) industri pengolahan; (4) listrik, gas dan air bersih; (5) konstruksi/bangunan; (6) perdagangan, hotel dan restoran; (7) pengangkutan dan komunikasi; (8) keuangan persewaan dan jasa perusahaan; (9) jasa (BPS (Badan Pusat Statistik) Berau, 1999). Sembilan sektor tersebut dikelompokkan dalam sektor primer (pertanian dan pertambangan), sektor sekunder (industri pengolahan, listrik, gas dan air bersih, dan bangunan) dan sektor tersier (perdagangan, pengangkutan, bank, dan jasa) (BPS, 2005).

Perkembangan pembangunan perekonomian daerah tergantung dari kondisi masing-masing daerah. Pembangunan ekonomi di Kabupaten Berau dapat diketahui dengan melihat indikator yang dapat mencerminkan seluruh kegiatan ekonomi yang telah dilaksanakan melalui indikator PDRB (Produk Domestik Regional Bruto) yang diuraikan melalui pertumbuhan PDRB dan peranan sektoral (BPS Berau, 2002)

Harapan bangkitnya perekonomian Kabupaten Berau dari krisis ekonomi semakin besar dengan adanya kebijakan otonomi daerah. Hal ini ditunjukkan oleh meningkatnya PDRB Kabupaten Berau secara terus menerus sesudah krisis dari tahun ke tahun. PDRB atas dasar harga konstan naik dari 2.784.297 juta rupiah pada tahun 2006 menjadi 4.602.168 juta rupiah untuk tahun 2010, dengan demikian telah terjadi peningkatan. Pada tahun 2011 laju PDRB Kabupaten Berau mencapai 8,04 persen dibandingkan tahun 2006 sebesar 5.08 persen. Pembangunan ekonomi di Kabupaten Berau yang dicirikan dengan peningkatan laju PDRB akan mempengaruhi peran kontribusi sektor-sektor dalam perekonomian.

Pengkajian peran sektor ini penting bila dikaitkan dengan kegiatan ekonomi yang strategis dan peralihan keadaan sosial yang diakibatkan oleh adanya perubahan struktur dari pembangunan yang bersifat agraris menjadi pembangunan yang non agraris. Hal ini sesuai dengan konsep perubahan struktur ekonomi menurut Djojohadikusumo (1994) berupa peralihan dan pergeseran dari kegiatan sektor primer ke sektor sekunder dan tersier.

Peranan sektoral terhadap pembangunan ekonomi digambarkan oleh distribusi masingmasing sektor terhadap total PDRB. Gambaran tentang sektor unggulan yang memiliki kontribusi terhadap pembangunan ekonomi daerah sangat diperlukan oleh Pemerintah Kabupaten Berau sehingga dari dasar gambaran tersebut dapat diketahui potensi-potensi tiap sektor dalam mendorong perekonomian. Berdasarkan uraian tersebut diatas, dapat disimpulkan bahwa sangat relevan untuk melakukan penelitian berjudul "Analisis Pergeseran Struktur Ekonomi Kabupaten Berau Sebelum dan Sesudah Otonomi Daerah".

\section{Rumusan Masalah}

Sektor apa saja yang mengalami pergeseran yang besar dalam mempengaruhi struktur ekonomi Kabupaten Berau dan laju pertumbuhan ekonomi Kalimantan Timur sebelum dan setelah otonomi daerah? Dan apakah pertumbuhan ekonomi Provinsi Kalimantan Timur berpengaruh positif terhadap pergeseran struktur ekonomi Kabupaten Berau sebelum dan setelah otonomi daerah?

\section{Tujuan Penelitian}

Berdasarkan rumusan masalah diatas, maka tujuan penelitian adalah untuk menganalisis pola struktur ekonomi yang terjadi di Kabupaten Berau sebelum dan setelah otonomi daerah, serta menganalisis pergeseran struktur ekonomi di Kabupaten Berau sebelum dan setelah otonomi daerah. 


\section{Kerangka Teori}

\subsection{Teori Pertumbuhan dan Pembangunan Ekonomi}

Pembahasan mengenai masalah pertumbuhan dan pembangunan ekonomi sering kali kita dengar dalam pembahasan ilmu ekonomi. Kedua istilah tersebut seolah-olah memiliki makna yang sama, namun ternyata tidak demikian. Ahli-ahli ekonomi di masa ekonomi klasik, banyak menyoroti masalah pertumbuhan ekonomi meskipun mereka menyebutnya sebagai pembangunan ekonomi. Adam smith dalam bukunya yang berjudul: An inquiry Into The Nature and Causes of The Wealth of Nation menganalisis berkembangnya suatu Negara (Sukirno 2006 : 275). Menurut pandangannya sistem mekanisme pasar akan memaksimalkan tingkat pembangunan ekonomi yang dapat dicapai suatu masyarakat. Sistem mekanisme pasar adalah kebebasan yang meksimal kepada para pelaku ekonomi untuk melakukan kegiatan ekonomi yang disukai dan meminimalisir campur tangan pemerintah dalam perekonomian.

Teori pembangunan ekonomi yang paling banyak mendapatkan perhatian adalah teori tahap-tahap pertumbuhan oleh Rostow. Rostow menitikberatkan analisis pembangunan dan aspek proses. Menurut Rostow dalam Kuncoro (2000 : 45) proses pembangunan dapat dibedakan menjadi lima tahap dan setiap negara dapat digolongkan ke dalam salah satu dari kelima tahapan tersebut :

1. Tahap Perekonomian Tradisional

2. Tahap Persyarat untuk Lepas Landas

Proses ini merupakan proses transisi dari masyarakat agraris menuju masyarakat industri. Sektor industry mulai berkembang, namun sektor primer masih memegang peranan penting.

3. Tahap Lepas Landas

Pada tahap ini, diantaranya ditandai perkembangan salah satu atau beberapa dari proses manufaktur penting dengan laju pertumbuhan tinggi.

4. Tahap menuju Kedewasaan

Masyarakat sudah efektif menggunakan teknologi modern dan salah satu cirri yang bersifat non ekonomi adalah struktur dan keahlian tenaga kerja mengalami perubahan.

5. Tahap Konsumsi Tinggi

Masyarakat lebih menekankan pada permasalahan konsumsi dan kesejahteraan, dengan berusaha untuk meningkatkan konsumsi ke barang-barang mewah dan awet.

\subsection{Teori Perubahan Struktur Ekonomi}

Pembangunan ekonomi dalam jangka panjang akan membawa perubahan mendasar dalam struktur ekonomi, semakin tinggi laju pertumbuhan ekonomi yang diikuti dengan semakin cepat proses peningkatan pandapatan per kapita masyarakat maka semakin cepat pula perubahan struktur ekonomi di suatu Negara (Tambunan 2001 : 59). Secara umum struktur ekonomi terbagi menjadi 3 sektor yaitu sektor primer, sektor sekunder dan sektor tersier (Sukirno 2006 : 75).

Benerapa Negara seperti Inggris, Prancis, Jerman dan negara-negara maju lainnya yang telah mengalami fase-fase dalam perubahan struktur ekonomi. Seperti penelitian yang dilakukan oleh Kuznets dalam Sukirno (2006 : 77) membuat kesimpulan mengenai corak perubahan persentasi sumbangan berbagai sektor dalam pembangunan ekonomi di ketiga belas Negara maju sebagai berikut :

1. Sumbangan sektor pertanian kepada produksi nasional telah menurun di dua belas dari tiga belas negara yang diteliti. Umumnya pada taraf permulaan dari pembangunan ekonomi, 
peranan sektor ini setengah dan bahkan duapertiga dari seluruh produksi nasional. Pada akhir masa observasi, peranan sektor pertanian hanya mencapai $20 \%$ atau kurang, bahkan di beberapa Negara peranannya lebih rendah dari $10 \%$.

2. Di duabelas negara, peranan sektor industry dalam menghasilkan produksi nasional meningkat. Pada taraf permulaan, sumbangan sektor tersebut berkisar antara 20\%-30\% dari seluruh produksi nasional. Pada akhir observasi peranannya meningkat sebesar $20 \%$ sehingga pada akhirnya menyumbangkan $40 \%$ atau bahkan $50 \%$ dari produk nasional

3. Sektor jasa sumbangannya dalam menciptakan produksi nasional tidak mengalami perubahan yang berarti dan perubahan itu tidak konsisten sifatnya.

Kesimpulan dari uraian di atas adalah produksi sektor pertanian mengalami perkembangan yang lebih lambat dari perkembangan produksi nasional sementara perkembangan sektor industri lebih cepat dari perkembangan produksi nasional.

\subsection{Teori Pertumbuhan Ekonomi Wilayah}

Pertumbuhan ekonomi jangan hanya mengejar pertumbuhan ekonomi sektoral, namun perlu dipikirkan juga untuk meningkatkan pertumbuhan ekonomi wilayah. Hal ini dimaksudkan untuk pemerataan pembangunan ekonomi di seluruh wilayah Negara tersebut. Pada akhirnya pertumbuhan ekonomi wilayah akan berdampak pada pertumbuhan ekonomi nasional.

Pertumbuhan ekonomi wilayah menurut Boediono dalam Tarigan (2007 : 46) menyatakan bahwa ada ahli ekonomi yang memberikan defenisi bahwa pertumbuhan itu haruslah bersumber dari proses intern perekonomian tersebut, bukan merupakan bantuan/suntikan dana dari pemerintah pusat dan akan terhenti apabila bantuan tersebut dihentikan. Teori pertumbuhan jalur cepat (turnpike) diperkenalkan oleh Samuelson dalam Tarigan (2007 : 54) bahwa setiap wilayah perlu melihat sektor/komoditi apa yang memiliki potensi besar untuk dikembangkan, artinya dengan modal yang sama akan menghasilkan nilai tambah yang besar dan dapat berproduksi dalam waktu relative singkat. Kemudian mensinergikan dengan sektor-sektor lain yang saling terkait dan mendukung. Sehingga pertumbuhan sektor yang satu akan mendorong sektor lain.

5. Metode Penelitian

\subsection{Jenis Penelitian}

Penelitian ini menggunakan data time series selama 18 Tahun yaitu dari tahun 1993 sampai 2011 sebelum dan sesudah otonomi daerah pada tahun 2000, sebelum otoda tahun $1993 \mathrm{~s} / \mathrm{d} 2000$ dan setelah otoda tahun $2000 \mathrm{~s} / \mathrm{d} 2011$.

\subsection{Analisis Data}

Alat analisis yang digunakan adalah analisis shift share.

\section{Hasil Penelitian}

\subsection{Objek Penelitian}

Kabupaten Berau merupakan bagian dari propinsi Kalimantan Timur yang letaknya dibagian utara propinsi tersebut dimana luas wilayahnya terdiri dari daratan dan lautan yaitu seluas 34.127 $\mathrm{Km}^{2}$. Letak daerah ini berada tidak jauh dari Garis Khatulistiwa dengan posisi berada antara $116^{\circ}$ sampai dengan $119^{\circ}$ Bujur Timur dan $1^{\circ}$ sampai dengan $2^{\circ} 33^{\prime}$ Lintang Utara.

Pada tahun 2002 terdiri atas 9 kecamatan dengan jumlah desa sebanyak 91 desa dan 7 kelurahan. Sedangkan pada tahun 2004 terjadi penambahan 2 kecamatan baru yang merupakan pemekaran dari kecamatan lama, yaitu Kecamatan Maratua dan Kecamatan Tabalar. Pada tahun 2005 terjadi lagi 
pemekaran 2 kecamatan yaitu Kecamatan Biatan dan Kecamatan Batu Putih. Sampai dengan tahun 2009 jumlah kecamatan di Kabupaten Berau sebanyak 13 kecamatan dengan 97 desa, 10 kelurahan dan 2 UPT.

Penduduk tahun 2010 khususnya di Kabupaten Berau menunjukkan Perkembengan yang sangat signifikan dibanding tahun sebelumnya yaitu ditahun 2009 jumlah penduduk sebesar 174.661 jiwa, sedangkan pada tahun 2010 sebesar 179.079 jiwa sehingga mengalami perkembangan sebesar 2,47 persen.

\subsection{Pendekatan Menurut Tahun Perhitungan Sebelum Otonomi Daerah}

a. Tahun $1993-1994$

Sektor Tersier mendominasi pertumbuhan PDRB Kabupaten Berau Tahun 1993-1994. Sektor perdagangan, hotel dan restoran, pengangkutan dan komunikasi, keuangan dan jasa perusahaan dan jasa-jasa memberikan sumbangan laju pertumbuhan PDRB Kabupaten Berau secara keseluruhan mencapai Rp. 46.388 juta. Kemudian sektor primer dengan sektor Pertanian, pertambangan dan penggalian memberikan sumbangan total mencapai Rp. 13.417 juta. Terakhir sektor sekunder dengan sektor industri pengolahan, listrik gas dan air bersih, bangunan memberikan kontribusi total sebesar Rp. 4.085 juta. Pada tahun 1993-1994 sektor tersier mendominasi pertumbuhan PDRB Kabupaten Berau.

b. Tahun $1994-1995$

Sektor Tersier mendominasi pertumbuhan PDRB Kabupaten Berau Tahun 1994-1995. Sektor perdagangan, hotel dan restoran, pengangkutan dan komunikasi, keuangan dan jasa perusahaan dan jasa-jasa memberikan sumbangan laju pertumbuhan PDRB Kabupaten Berau secara keseluruhan mencapai Rp. 46.388 juta. Kemudian sektor primer dengan sektor Pertanian, pertambangan dan penggalian memberikan sumbangan total mencapai Rp. 13.417 juta. Terakhir sektor sekunder dengan sektor industri pengolahan, listrik gas dan air bersih, bangunan memberikan kontribusi total sebesar Rp. 4.085 juta. Pada tahun 1994-1995 sektor tersier mendominasi pertumbuhan PDRB Kabupaten Berau.

c. Tahun $1995-1996$

Sektor Tersier mendominasi pertumbuhan PDRB Kabupaten Berau Tahun 1995-1996. Sektor perdagangan, hotel dan restoran, pengangkutan dan komunikasi, keuangan dan jasa perusahaan dan jasa-jasa memberikan sumbangan laju pertumbuhan PDRB Kabupaten Berau secara keseluruhan mencapai Rp. 46.388 juta. Kemudian sektor primer dengan sektor Pertanian, pertambangan dan penggalian memberikan sumbangan total mencapai Rp. 13.417 juta. Terakhir sektor sekunder dengan sektor industri pengolahan, listrik gas dan air bersih, bangunan memberikan kontribusi total sebesar Rp. 4.085 juta. Pada tahun 1995-1996 sektor tersier mendominasi pertumbuhan PDRB Kabupaten Berau.

d. Tahun $1996-1997$

Sektor sekunder mendominasi pertumbuhan PDRB Kabupaten Berau Tahun 1996-1997. sektor industri pengolahan, listrik gas dan air bersih, bangunan memberikan kontribusi total Rp. 39.010 juta. Kemudian sektor primer dengan sektor Pertanian, pertambangan dan penggalian memberikan sumbangan total mencapai Rp. 20.461 juta. Terakhir sektor tersier dengan Sektor perdagangan, hotel dan restoran, pengangkutan dan komunikasi, keuangan dan jasa perusahaan dan jasa-jasa memberikan sumbangan laju pertumbuhan PDRB Kabupaten Berau dengan total sumbangan minus Rp. 66.458 juta. Pada tahun 1996-1997 sektor sekunder mendominasi pertumbuhan PDRB Kabupaten Berau.

e. Tahun $1997-1998$ 
Sektor Primer mendominasi pertumbuhan PDRB Kabupaten Berau Tahun 1997-1998. sektor Pertanian, pertambangan dan penggalian memberikan sumbangan mencapai Rp. 34.971 juta. Kemudian sektor sekunder dengan sektor industri pengolahan, listrik gas dan air bersih, bangunan memberikan kontribusi total mencapai Rp. 32.004 juta. Terakhir sektor tersier dengan Sektor perdagangan, hotel dan restoran, pengangkutan dan komunikasi, keuangan dan jasa perusahaan dan jasa-jasa memberikan sumbangan laju pertumbuhan PDRB Kabupaten Berau secara keseluruhan Rp. 17.628 juta. Pada tahun 1997-1998 sektor primer mendominasi pertumbuhan PDRB Kabupaten Berau.

f. Tahun $1998-1999$

Sektor Tersier mendominasi pertumbuhan PDRB Kabupaten Berau Tahun 1998-1999. Sektor perdagangan, hotel dan restoran, pengangkutan dan komunikasi, keuangan dan jasa perusahaan dan jasa-jasa memberikan sumbangan laju pertumbuhan PDRB Kabupaten Berau secara keseluruhan mencapai Rp. 23.724 juta. Kemudian sektor sekunder dengan sektor industri pengolahan, listrik gas dan air bersih, bangunan memberikan kontribusi total sebesar Rp. 10.898 juta. Terakhir sektor primer dengan sektor Pertanian, pertambangan dan penggalian memberikan sumbangan total mencapai Rp. 1.631 juta. Pada tahun 1998-1999 sektor tersier mendominasi pertumbuhan PDRB Kabupaten Berau.

g. Tahun $1999-2000$

Sektor Primer mendominasi pertumbuhan PDRB Kabupaten Berau Tahun 1999-2000. sektor Pertanian, pertambangan dan penggalian memberikan sumbangan mencapai Rp. 37.849 juta. Kemudian sektor tersier dengan Sektor perdagangan, hotel dan restoran, pengangkutan dan komunikasi, keuangan dan jasa perusahaan dan jasa-jasa memberikan sumbangan laju pertumbuhan PDRB Kabupaten Berau secara keseluruhan Rp. 28.015 juta. Terakhir sektor sekunder dengan sektor industri pengolahan, listrik gas dan air bersih, bangunan memberikan kontribusi total mencapai Rp. 10.167 juta. Pada tahun 1999-2000 sektor primer mendominasi pertumbuhan PDRB Kabupaten Berau.

\subsection{Pendekatan Menurut Tahun Perhutungan Sesudah Otonomi Daerah}

a. Tahun $2000-2001$

Sektor Primer mendominasi pertumbuhan PDRB Kabupaten Berau Tahun 2000-2001. sektor Pertanian, pertambangan dan penggalian memberikan sumbangan mencapai Rp. 33.257 juta. Kemudian sektor tersier dengan Sektor perdagangan, hotel dan restoran, pengangkutan dan komunikasi, keuangan dan jasa perusahaan dan jasa-jasa memberikan sumbangan laju pertumbuhan PDRB Kabupaten Berau secara keseluruhan Rp. 20.656 juta. Terakhir sektor sekunder dengan sektor industri pengolahan, listrik gas dan air bersih, bangunan memberikan kontribusi total mencapai Rp. 6.761 juta. Pada tahun 2000-2001 sektor primer mendominasi pertumbuhan PDRB Kabupaten Berau.

b. Tahun $2001-2002$

Sektor Primer mendominasi pertumbuhan PDRB Kabupaten Berau Tahun 2001-2002. sektor Pertanian, pertambangan dan penggalian memberikan sumbangan mencapai Rp. 83.385 juta. Kemudian sektor tersier dengan Sektor perdagangan, hotel dan restoran, pengangkutan dan komunikasi, keuangan dan jasa perusahaan dan jasa-jasa memberikan sumbangan laju pertumbuhan PDRB Kabupaten Berau secara keseluruhan Rp. 23.385 juta. Terakhir sektor sekunder dengan sektor industri pengolahan, listrik gas dan air bersih, bangunan memberikan kontribusi total mencapai Rp. 5.543 juta. Pada tahun 2001-2002 sektor primer mendominasi pertumbuhan PDRB Kabupaten Berau.

c. Tahun $2002-2003$ 
Sektor Primer mendominasi pertumbuhan PDRB Kabupaten Berau Tahun 2002-2003. sektor Pertanian, pertambangan dan penggalian memberikan sumbangan mencapai Rp. 71.818 juta. Kemudian sektor tersier dengan Sektor perdagangan, hotel dan restoran, pengangkutan dan komunikasi, keuangan dan jasa perusahaan dan jasa-jasa memberikan sumbangan laju pertumbuhan PDRB Kabupaten Berau secara keseluruhan Rp. 17.818 juta. Terakhir sektor sekunder dengan sektor industri pengolahan, listrik gas dan air bersih, bangunan memberikan kontribusi total mencapai Rp. 8.504 juta. Pada tahun 2002-2003 sektor primer mendominasi pertumbuhan PDRB Kabupaten Berau

d. Tahun $2003-2004$

Sektor Primer mendominasi pertumbuhan PDRB Kabupaten Berau Tahun 2003-2004. sektor Pertanian, pertambangan dan penggalian memberikan sumbangan mencapai Rp. 37.785 juta. Kemudian sektor tersier dengan Sektor perdagangan, hotel dan restoran, pengangkutan dan komunikasi, keuangan dan jasa perusahaan dan jasa-jasa memberikan sumbangan laju pertumbuhan PDRB Kabupaten Berau secara keseluruhan Rp. 17.604 juta. Terakhir sektor sekunder dengan sektor industri pengolahan, listrik gas dan air bersih, bangunan memberikan kontribusi total mencapai Rp. 9.372 juta. Pada tahun 2003-2004 sektor primer mendominasi pertumbuhan PDRB Kabupaten Berau.

e. Tahun $2004-2005$

Sektor Primer mendominasi pertumbuhan PDRB Kabupaten Berau Tahun 2004-2005. sektor Pertanian, pertambangan dan penggalian memberikan sumbangan mencapai Rp. 98.322 juta. Kemudian sektor tersier dengan Sektor perdagangan, hotel dan restoran, pengangkutan dan komunikasi, keuangan dan jasa perusahaan dan jasa-jasa memberikan sumbangan laju pertumbuhan PDRB Kabupaten Berau secara keseluruhan Rp. 20.094 juta. Terakhir sektor sekunder dengan sektor industri pengolahan, listrik gas dan air bersih, bangunan memberikan kontribusi total mencapai Rp. 10.353 juta. Pada tahun 2004-2005 sektor primer mendominasi pertumbuhan PDRB Kabupaten Berau.

f. Tahun $2005-2006$

Sektor Primer mendominasi pertumbuhan PDRB Kabupaten Berau Tahun 2005-2006. sektor Pertanian, pertambangan dan penggalian memberikan sumbangan mencapai Rp. 100.128 juta. Kemudian sektor tersier dengan Sektor perdagangan, hotel dan restoran, pengangkutan dan komunikasi, keuangan dan jasa perusahaan dan jasa-jasa memberikan sumbangan laju pertumbuhan PDRB Kabupaten Berau secara keseluruhan Rp. 24.202 juta. Terakhir sektor sekunder dengan sektor industri pengolahan, listrik gas dan air bersih, bangunan memberikan kontribusi total mencapai Rp. 10.343 juta. Pada tahun 2005-2006 sektor primer mendominasi pertumbuhan PDRB Kabupaten Berau.

g. Tahun $2006-2007$

Sektor Primer mendominasi pertumbuhan PDRB Kabupaten Berau Tahun 2006-2007. sektor Pertanian, pertambangan dan penggalian memberikan sumbangan mencapai Rp. 103.251 juta. Kemudian sektor tersier dengan Sektor perdagangan, hotel dan restoran, pengangkutan dan komunikasi, keuangan dan jasa perusahaan dan jasa-jasa memberikan sumbangan laju pertumbuhan PDRB Kabupaten Berau secara keseluruhan Rp. 39.425 juta. Terakhir sektor sekunder dengan sektor industri pengolahan, listrik gas dan air bersih, bangunan memberikan kontribusi total mencapai Rp. 15.966 juta. Pada tahun 2006-2007 sektor primer mendominasi pertumbuhan PDRB Kabupaten Berau.

h. Tahun $2007-2008$

Sektor Primer mendominasi pertumbuhan PDRB Kabupaten Berau Tahun 2007-2008. sektor Pertanian, pertambangan dan penggalian memberikan sumbangan mencapai Rp. 233.663 juta. Kemudian sektor tersier dengan Sektor perdagangan, hotel dan restoran, pengangkutan dan 
komunikasi, keuangan dan jasa perusahaan dan jasa-jasa memberikan sumbangan laju pertumbuhan PDRB Kabupaten Berau secara keseluruhan Rp. 39.235 juta. Terakhir sektor sekunder dengan sektor industri pengolahan, listrik gas dan air bersih, bangunan memberikan kontribusi total mencapai Rp. 7.273 juta. Pada tahun 2007-2008 sektor primer mendominasi pertumbuhan PDRB Kabupaten Berau

i. Tahun $2008-2009$

Sektor Primer mendominasi pertumbuhan PDRB Kabupaten Berau Tahun 2008-2009. sektor Pertanian, pertambangan dan penggalian memberikan sumbangan mencapai Rp. 151.936 juta. Kemudian sektor tersier dengan Sektor perdagangan, hotel dan restoran, pengangkutan dan komunikasi, keuangan dan jasa perusahaan dan jasa-jasa memberikan sumbangan laju pertumbuhan PDRB Kabupaten Berau secara keseluruhan Rp. 37.521 juta. Terakhir sektor sekunder dengan sektor industri pengolahan, listrik gas dan air bersih, bangunan memberikan kontribusi total mencapai Rp. 3.316 juta. Pada tahun 2008-2009 sektor primer mendominasi pertumbuhan PDRB Kabupaten Berau.

j. Tahun $2009-2010$

Sektor Primer mendominasi pertumbuhan PDRB Kabupaten Berau Tahun 2009-2010. sektor Pertanian, pertambangan dan penggalian memberikan sumbangan mencapai Rp. 152.862 juta. Kemudian sektor tersier dengan Sektor perdagangan, hotel dan restoran, pengangkutan dan komunikasi, keuangan dan jasa perusahaan dan jasa-jasa memberikan sumbangan laju pertumbuhan PDRB Kabupaten Berau secara keseluruhan Rp. 30.746 juta. Terakhir sektor sekunder dengan sektor industri pengolahan, listrik gas dan air bersih, bangunan memberikan kontribusi total mencapai Rp. 2.578 juta. Pada tahun 2009-2010 sektor primer mendominasi pertumbuhan PDRB Kabupaten Berau.

k. Tahun $2010-2011$

Sektor Primer mendominasi pertumbuhan PDRB Kabupaten Berau Tahun 2010-2011. sektor Pertanian, pertambangan dan penggalian memberikan sumbangan mencapai Rp. 318.845 juta. Kemudian sektor tersier dengan Sektor perdagangan, hotel dan restoran, pengangkutan dan komunikasi, keuangan dan jasa perusahaan dan jasa-jasa memberikan sumbangan laju pertumbuhan PDRB Kabupaten Berau secara keseluruhan Rp. 43.783 juta. Terakhir sektor sekunder dengan sektor industri pengolahan, listrik gas dan air bersih, bangunan memberikan kontribusi total mencapai Rp. 2.686 juta. Pada tahun 2010-2011 sektor primer mendominasi pertumbuhan PDRB Kabupaten Berau.

7. Simpulan

7.1. Besaran pertambahan PDRB Kabupaten Berau yang disumbangkan oleh masing-masing sektor ekonomi selama periode penelitian memiliki kontribusi yang berbeda-beda. Perbedaan tersebut dengan sendirinya akan membentuk suatu pola. Pola struktur ekonomi dalam penelitian ini yaitu sebelum otonomi daerah tahun 1993-2000 dan setelah otonomi daerah tahun 2000-2011 dapat dibagi menjadi 2 (dua) pola yaitu pola struktur ekonomi yang cendrung konstan dan pola struktur ekonomi yang berfluktuatif.

7.2. Sektor ekonomi yang memiliki kecendrungan berpola fluktuatif terjadi sebelum otonomi daerah tahun 1993-2000 dimana pada tahun 1993-1995 sektor primer yang mendominasi dan pada tahun 1996-1997 sektor sekunder yang mendominasi pada tahun 1997-1998 sektor primer yang mendominasi pada tahun 1998-1999 kembali sektor tersier kembali yang mendominasi dan pada tahun 1999-2000 sektor primer yang mendominasi, sedangkan sektor ekonomi yang memiliki kecendrungan berpola konstan terjadi setelah otonomi daerah yaitu dari tahun 2000-2011 dimana sektor primer dominan disusul sektor tersier dan terakhir sektor sekunder.

8. Referensi

A. Pinem, 2009, Analisis Hubungan Antara Alokasi anggaran Pembangunan Terhadap

Pertumbuhan PDRB DKI Jakarta, UI, Jakarta 
BPS Kabupaten Berau, 2006, Produk Domentik Regional Bruto Menurut Lapangan Usaha Kabupaten Berau 2006, Tanjung Redeb

BPS Kabupaten Berau, 2007, Produk Domentik Regional Bruto Menurut Lapangan Usaha Kabupaten Berau 2007, Tanjung Redeb

BPS Kabupaten Berau, 2008, Produk Domentik Regional Bruto Menurut Lapangan Usaha Kabupaten Berau 2008, Tanjung Redeb

BPS Kabupaten Berau, 2009, Produk Domentik Regional Bruto Menurut Lapangan Usaha Kabupaten Berau 2009, Tanjung Redeb

BPS Kabupaten Berau, 2010, Produk Domentik Regional Bruto Menurut Lapangan Usaha Kabupaten Berau 2010, Tanjung Redeb

BPS Kabupaten Berau, 2011, Produk Domentik Regional Bruto Menurut Lapangan Usaha Kalimantan Timur Tahun 1993-2011, BPS Kalimanatan Timur

Kuncoro, Mudrajat, 2000. Ekonomi Pembangunan Teori, Masalah dan kebijakan. Edisi Kedua, Yogyakarta, UPP AMP YKPN

Nadira, 2012, Analisis Struktur Ekonomi dan Sektor Unggulan Kabupaten Mamuju Sulawesi Barat Periode 2004-2009, UNHAS, Makassar

Ridwan, 2008, Analisis potensi ekonomi dengan penentuan sektor basis antar daerah di Sulawesi Tengah, UGM, Yogyakarta

Sukirno, Sadono, 1999, Makroekonomi Teori Pengantar. Edisi Ketiga, Jakarta : PT. Raja Grafindo Persana

Tambunan, Tulus T.H. 2000, Perekonomian Indonesia Teori dan Temuan Empiris, Edisi Kedua, Jakarta : Ghalia Indonesia

Tarigan, Robinson, 2007, Ekonomi Regional Teori dan Aplikasi, Edisi 4, Bumi Aksara, Jakarta

Usya, 2006, Analisis Struktur Ekonomi dan Identifikasi Sektor Unggulan di Kabupaten Subang, Nurlatifa, IPB, Bogor

Yuni Sofyan, 2012, Analisis Struktur Ekonomi Kota Samarinda 2000-2010, Tesis, Universitas Mulawarman 